\title{
Modifications of diketopiperazines assembled by cyclodipeptide synthases with cytochrome $P_{450}$ enzymes
}

\author{
Lauritz Harken $^{1}$. Shu-Ming $\mathrm{Li}^{1}$ (D) \\ Received: 17 December 2020 / Revised: 4 February 2021 / Accepted: 10 February 2021 / Published online: 24 February 2021 \\ (C) The Author(s) 2021
}

\begin{abstract}
2,5-Diketopiperazines are the smallest cyclic peptides comprising two amino acids connected via two peptide bonds. They can be biosynthesized in nature by two different enzyme families, either by nonribosomal peptide synthetases or by cyclodipeptide synthases. Due to the stable scaffold of the diketopiperazine ring, they can serve as precursors for further modifications by different tailoring enzymes, such as methyltransferases, prenyltransferases, oxidoreductases like cyclodipeptide oxidases, 2oxoglutarate-dependent monooxygenases and cytochrome $\mathrm{P}_{450}$ enzymes, leading to the formation of intriguing secondary metabolites. Among them, cyclodipeptide synthase-associated $\mathrm{P}_{450} \mathrm{~s}$ attracted recently significant attention, since they are able to catalyse a broader variety of astonishing reactions than just oxidation by insertion of an oxygen. The $\mathrm{P}_{450}$-catalysed reactions include hydroxylation at a tertiary carbon, aromatisation of the diketopiperazine ring, intramolecular and intermolecular carboncarbon and carbon-nitrogen bond formation of cyclodipeptides and nucleobase transfer reactions. Elucidation of the crystal structures of three $\mathrm{P}_{450} \mathrm{~S}$ as cyclodipeptide dimerases provides a structural basis for understanding the reaction mechanism and generating new enzymes by protein engineering. This review summarises recent publications on cyclodipeptide modifications by $\mathrm{P}_{450} \mathrm{~S}$.
\end{abstract}

Key Points

- Intriguing reactions catalysed by cyclodipeptide synthase-associated cytochrome $P_{450} S$

- Homo- and heterodimerisation of diketopiperazines

- Coupling of guanine and hypoxanthine with diketopiperazines

Keywords Cyclodipeptides · Cytochrome P450 - Diversity of cyclodipeptides $\cdot$ Enzymatic modification

\section{Introduction}

Natural products derived from microbial, plant or animal organisms constitute the largest source for medicinal drugs, either in unmodified form or as chemically modified derivatives (Newman and Cragg 2020). Mining of microbial genome sequences has strongly accelerated the elucidation process of biosynthetic pathways of known metabolites and revealed the presence of a large number of unknown biosynthetic gene clusters (BGCs). They are responsible for new extraordinary

Shu-Ming Li

shuming.li@staff.uni-marburg.de

1 Institut für Pharmazeutische Biologie und Biotechnologie,

Fachbereich Pharmazie, Philipps-Universität Marburg,

Robert-Koch-Str. 4, 35037 Marburg, Germany enzymes and an astonishing variety of secondary metabolites. As these BGCs are usually silent and their original triggers are diverse, unspecific or even hazardous, often only a targeted activation either in the natural host or in optimised expression hosts provides insights into their functions. The characterised secondary metabolite enzymes are able to catalyse stereoselective, stereospecific, efficient and energetically disfavoured reactions.

Cyclodipeptides (CDPs) are the smallest possible cyclic peptides from two amino acids with two peptide bonds. In nature, CDPs are assembled by either nonribosomal peptide synthetases (NRPSs) mostly in fungi or by cyclodipeptide synthases (CDPSs) mainly in bacteria. These two enzyme families differ not only in protein size and sequences but also in substrates and reaction mechanisms. NRPSs are large multi-modular proteins using free amino acids as substrates (Izoré and Cryle 2018; Payne et al. 2017). Diketopiperazine 
Fig. 1 Cyclodipeptide formation catalysed by cyclodipeptide synthases with aminoacyl-tRNAs as substrates

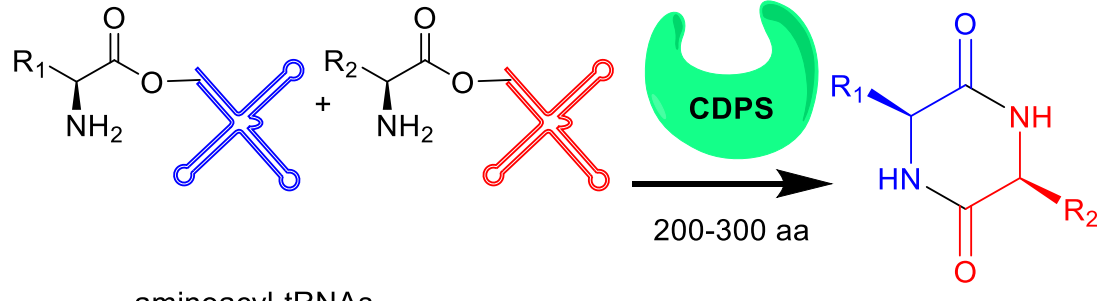

aminoacyl-tRNAs

$R_{1}$ and $R_{2}$ : amino acid side chain

cyclodipeptide
(DKP)-forming NRPSs are dimodular enzymes with typical peptide chain lengths of about 2300-2500 amino acids (Xu et al. 2014). In comparison, CDPSs consist only of 200-300 amino acids and hijack the activated aminoacyl-tRNAs from the ribosomal machinery for CDP formation (Fig. 1) (Gondry et al. 2009, 2018; Moutiez et al. 2017).

\section{Modification of CDPs by tailoring enzymes}

The DKP ring of the CDPs has an increased stability against proteolysis, in comparison to acyclic dipeptides (Borthwick 2012), making it a stable scaffold for diverse modifications by tailoring enzymes such as oxidoreductases including 2oxoglutarate-dependent monooxygenases, cyclodipeptide oxidases (CDOs) and cytochrome $\mathrm{P}_{450}$ enzymes $\left(\mathrm{P}_{450} \mathrm{~s}\right)$, methyltransferases (MTs) and prenyltransferases (Borgman et al. 2019; Canu et al. 2020). Known CDP modification reactions by CDPS-associated tailoring enzymes are listed in Table 1. The products of CDPS-related pathways exhibit diverse pharmacological effects such as antibiotic (Cain et al. 2003), antifungal (Musetti et al. 2007; Ström et al. 2002), anti-inflammatory (Minelli et al. 2012), immunosuppressive (Waring and Beaver
1996) and antitumor activities (Yamazaki et al. 2012). Bicyclomycin, for example, is used as an antibiotic for treatment of traveller's diarrhoea caused by gram-negative bacteria such as E. coli, Klebsiella, Shigella or Salmonella species. It has a unique pharmacological mechanism by selectively inhibiting the bacterial transcription termination factor Rho and shows synergetic effects with other antibiotics (Kohn and Widger 2005; Lawson et al. 2016). Mycocyclosin is essential for the viability of Mycobacterium tuberculosis. The $\mathrm{P}_{450}$ enzyme CYP121 involved in its formation could be therefore considered an alternative target for potential drugs in the treatment of tuberculosis, which is still responsible for 1.5 million deaths worldwide per year (Harding 2020; McLean et al. 2008).

Several outstanding reviews have already outlined the variety of cyclodipeptides and their derivatives (Borgman et al. 2019; Canu et al. 2020; Giessen and Marahiel 2015; Moutiez et al. 2017). During the last years, CDPS-associated $\mathrm{P}_{450} \mathrm{~s}$ got more and more attraction. Seventeen members from this enzyme family have been proven to catalyse intriguing reactions. Their catalytic spectrum ranges from hydroxylation of a tertiary carbon, aromatisation, intramolecular C-C bond formation and DKP dimerisation, to transfer of nucleobases to a DKP unit, as exemplarily given in Fig. 2.

Table 1 Overview on enzymatic modifications of cyclodipeptides assembled by cyclodipeptide synthases

\begin{tabular}{|c|c|c|}
\hline Modification by tailoring enzymes & Organism & Reference \\
\hline a, $\beta$-dehydrogenation by cyclodipeptide oxidase & $\begin{array}{l}\text { Streptomyces noursei and related species } \\
\text { Nocardiopsis dassonvillei, N. alba, N. prasina }\end{array}$ & $\begin{array}{l}\text { (Giessen et al. 2013b; Lautru et al. 2002; Le } \\
\text { Chevalier et al. 2020; Mikulski et al. } \\
\text { 2020; Zhang et al. 2013) }\end{array}$ \\
\hline N-methylation at DKP ring by methyltransferase & $\begin{array}{l}\text { Actinosynnema mirum } \\
\text { S. youssoufiensis and related species }\end{array}$ & (Giessen et al. 2013a; Yao et al. 2020) \\
\hline Prenylation by prenyltransferase & Streptomyces youssoufiensis & (Yao et al. 2018) \\
\hline $\begin{array}{l}\text { Hydroxylation by 2-oxoglutarate dependent oxy- } \\
\text { genase and } \mathrm{P}_{450}\end{array}$ & Streptomyces cinnamoneus, Pseudomonas aeruginosa & $\begin{array}{l}\text { (Meng et al. 2018; Patteson et al. 2017; Vior } \\
\text { et al. 2018; Witwinowski et al. 2019) }\end{array}$ \\
\hline Aromatisation by $\mathrm{P}_{450}$ & Bacillus subtilis & (Cryle et al. 2010) \\
\hline Intramolecular $\mathrm{C}-\mathrm{C}$ bond formation by $\mathrm{P}_{450}$ & Mycobacterium tuberculosis & (Belin et al. 2009) \\
\hline Cyclodipeptide dimerisation by $\mathrm{P}_{450}$ & $\begin{array}{l}\text { Streptomyces species, Saccharopolyspora } \\
\text { antimicrobica }\end{array}$ & $\begin{array}{l}\text { (Liu et al. 2020; Shende et al. 2020; Sun et al. } \\
\text { 2020; Tian et al. 2018; Yu and Li 2019) }\end{array}$ \\
\hline Nucleobase addition by $\mathrm{P}_{450}$ & $\begin{array}{l}\text { Streptomyces purpureus, } S . \text { varsoviensis, } S . \\
\quad \text { monomycini S. lavendulae and S. xanthophaeus }\end{array}$ & $\begin{array}{l}\text { (Liu et al. 2019; Shi et al. 2019; Yu et al. } \\
\text { 2018, 2019) }\end{array}$ \\
\hline
\end{tabular}


Fig. 2 Examples of modification reactions catalysed by CDPSassociated P450s (highlighted in red)

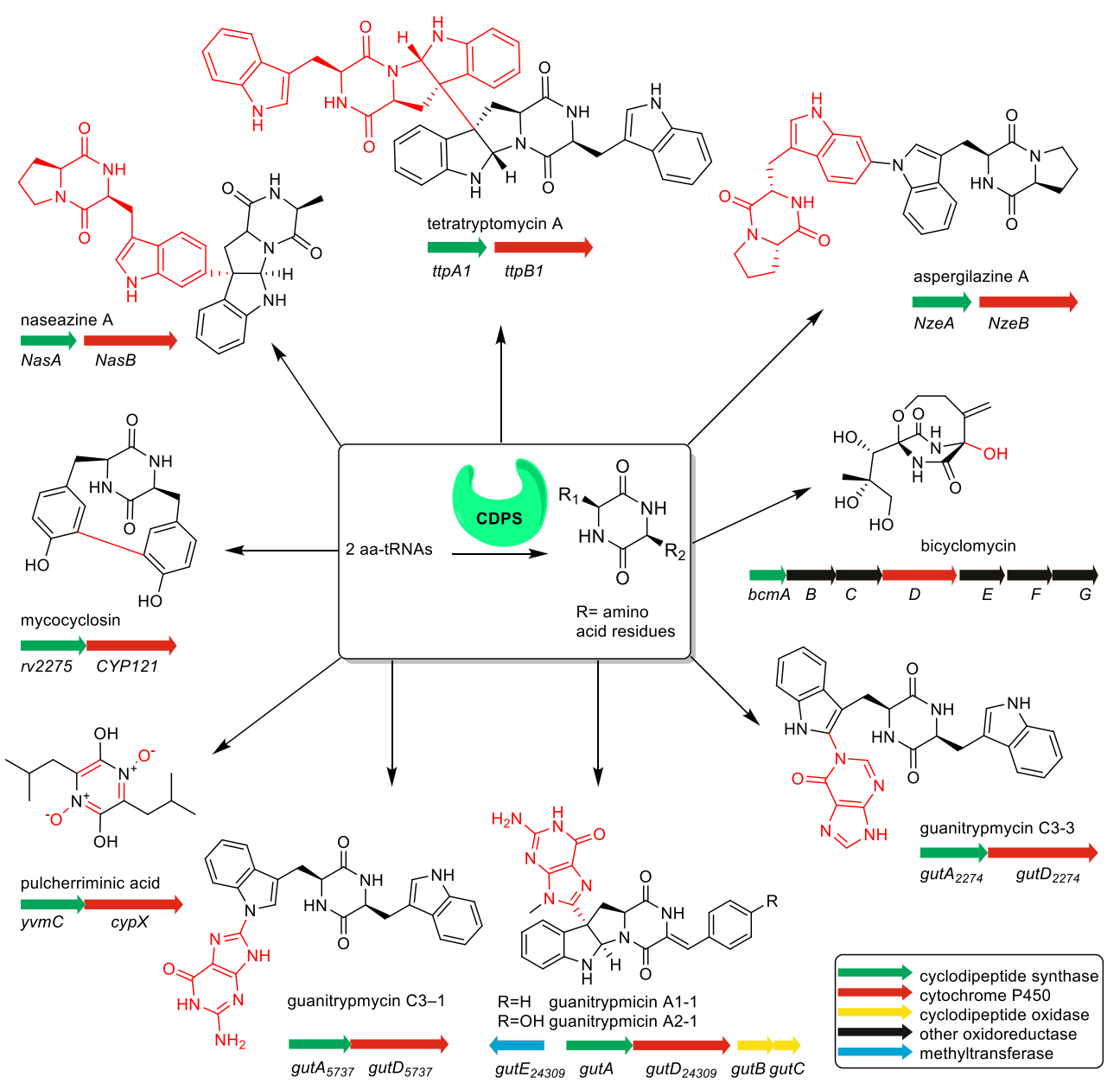

\section{Properties of $\mathbf{P}_{\mathbf{4 5 0}} \mathrm{S}$}

Cytochrome $\mathrm{P}_{450}$ enzymes represent an enzyme superfamily occurring almost ubiquitously throughout living organisms. In eukaryotes, they are usually bound to membranes, whereas bacterial members appear freely in the cytosol. They contribute a major part in carbon source assimilation, production of secondary metabolites and metabolism of xenobiotics (Chen et al. 2021). $\mathrm{P}_{450}$ s have different sizes, cofactors and electron donors as well as various shapes of substrate binding pockets. These features make them versatile enzymes performing a vast variety of stereoselective and stereospecific reactions. The enzymes of this family got their names based on the Soret peak at $450 \mathrm{~nm}$, when the reduced form is complexed with carbon monoxide (Klingenberg 1957). $\mathrm{P}_{450} \mathrm{~s}$ contain a haem acting as a monooxygenase by usually inserting or adding a single oxygen atom onto their substrates. Haem itself is a hexa-coordinated complex consisting of an iron ion in the middle of a planar porphyrin as tetradentate ligand. The iron ion is axially bound to the enzyme on one side and on the opposite side complexed with a molecule water in the resting state. Replacing the water molecule by a reactive oxygen species initiates the $\mathrm{P}_{450}$-catalysed reaction. The central iron ion state is changed from $\mathrm{Fe}^{\mathrm{IV}}$ to $\mathrm{Fe}^{\mathrm{II}}$ (Katagiri et al. 1968).

Bacterial $\mathrm{P}_{450} \mathrm{~S}$ are normally soluble proteins with around 400-500 amino acid residues and can be overproduced in $E$. coli for in vitro assays. They use usually ferredoxin and ferredoxin reductase as cofactors but are also able to accept electrons from heterologous redox partners (Rudolf et al. 2017).

\section{P450 as hydroxylase in the biosynthesis of bicyclomycin}

In the BGC of bicyclomycin from Streptomyces sapporensis, the $\mathrm{P}_{450} \mathrm{BcmD}$ acts as a hydroxylase (Fig. 3). The elucidation of the biosynthetic pathway was reported by two different groups in Streptomyces cinnamoneus ATCC 21532 (synonym Streptomyces sapporensis) (Meng et al. 2018; Patteson et al. 2017). A very similar BGC coding for bicyclomycin biosynthetic pathway was found in Pseudomonas aeruginosa SCV20265 (Vior et al. 2018). Several putative bicyclomycin BGCs have also been found in various gram-positive and 
Fig. $3 \mathrm{P}_{450}$ role in the biosynthesis of bicyclomycin in Streptomyces cinnamoneus

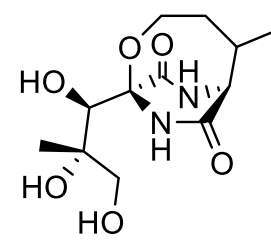

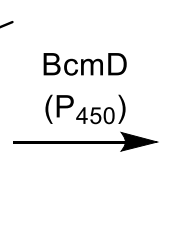

bicyclic hemiaminal
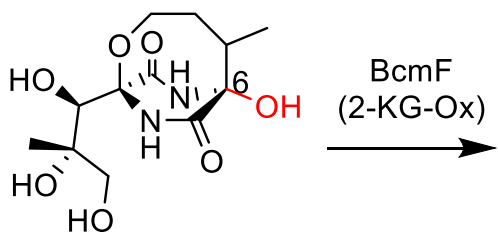

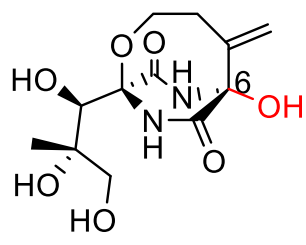

bicyclomycin gram-negative bacteria, suggesting gene transfer events across different bacterial species (Vior et al. 2018).

The CDP core of bicyclomycin consisting of L-isoleucine and L-leucine is modified by five non-haem mononuclear iron and 2-ketoglutarate-dependent oxidases and one $\mathrm{P}_{450}$. The bicyclic hemiaminal intermediate is hydroxylated by the $\mathrm{P}_{450} \mathrm{BcmD}$ and dehydrogenated by the 2-ketoglutaratedependent oxidase BcmF (Fig. 3).

\section{P450 as aromatase in the biosynthesis of pulcherriminic acid}

Pulcherriminic acid has already been isolated and identified in 1972 from Bacillus subtilis (Uffen and Canale-Parola 1972), whereas its biosynthetic pathway was elucidated 38 years later (Cryle et al. 2010). The BGC of pulcherriminic acid comprises merely two genes coding for a CPDS and a $\mathrm{P}_{450}$ enzyme. The CDP core is assembled from two L-leucine molecules by the CDPS YvmC and altered by the P450 CypX (also termed as CYP134A1) via a three-step oxidative transfer mechanism. The two nitrogen atoms of the DKP ring are oxidised to Noxides and the DKP ring is aromatised (Fig. 4). This aromatisation is claimed either via hydroxylation and subsequent water elimination or via a direct electron transfer reaction. Afterwards, the oxygen residues undergo a chelation with $2 \mathrm{x} \mathrm{Fe}^{3+}$ forming pulcherrimin.

\section{$\mathbf{P}_{450}$ catalysing intramolecular $\mathrm{C}-\mathrm{C}$ bond formation in the biosynthesis of mycocyclosin}

Most sequenced Mycobacterium tuberculosis strains share a two-gene BGC being responsible for the biosynthesis of mycocyclosin, an oxidised cYY product. The CDPS Rv2275 catalyses the condensation of two L-tyrosine molecules to<smiles>CC(C)C[C@@H]1NC(=O)[C@@H](CC(C)C)NC1=O</smiles>

cLL<smiles>[Y20][C@H](C)CC(C)Cc1c(O)[n+]([O-])c(CC(C)C)c(O)[n+]1[O-]</smiles>

pulcherriminic acid
Fig. $4 \mathrm{P}_{450}$-catalysed formation of pulcherriminic acid in Bacillus subtilis
cyclo-(L-Tyr-L-Tyr), which is then converted to mycocyclosin by the $\mathrm{P}_{450}$ enzyme Rv2276, commonly known as CYP121 (Belin et al. 2009). This conversion is an intramolecular C-C bond formation between the ortho-positions to the phenolic residues (Fig. 5). CYP121 shares high sequence homology with $\mathrm{P}_{450} \mathrm{~S}$ catalysing nucleobase transfer reactions ( $\mathrm{Yu}$ et al. 2018).

\section{$P_{450}$ S as transferases of nucleobases guanine and hypoxanthine}

Tryptophan is a frequent target of bacterial tailoring enzymes due to its electron-rich indole moiety (Alkhalaf and Ryan 2015). Very recently, bacterial $\mathrm{P}_{450}$ s from several Streptomyces species have been proven to catalyse the linkage of a guanine to a tryptophan residue of CDPs in the biosynthesis of guanitrypmycins and analogues (Liu et al. 2019; Shi et al. 2019; Yu et al. 2018). The elucidation of the biosynthetic pathways was achieved by heterologous expression in Streptomyces coelicolor, precursor feeding experiments and biochemical characterisation with recombinant and purified enzymes.

Four biosynthetic pathways for guanitrypmycins bearing a guanine moieties have been reported so far (Fig. 6), including the two-gene cluster from Streptomyces purpureus NRRL B5737 with the $\mathrm{P}_{450}$ GutD $_{5737}$ for coupling of guanine with cWW (Yu et al. 2018). Two very similar BGCs consisting of five genes were identified in Streptomyces monomycini NRRL B-24309 and Streptomyces varsoviensis NRRL B-3589. These genes code for four functional enzymes, i.e. CDPS, CDO encoded by two genes, $\mathrm{P}_{450}$ and MT. Both $\mathrm{P}_{450}$ enzymes, GutD ${ }_{24309}$ from strain B-24309 and GutD ${ }_{3589}$ from

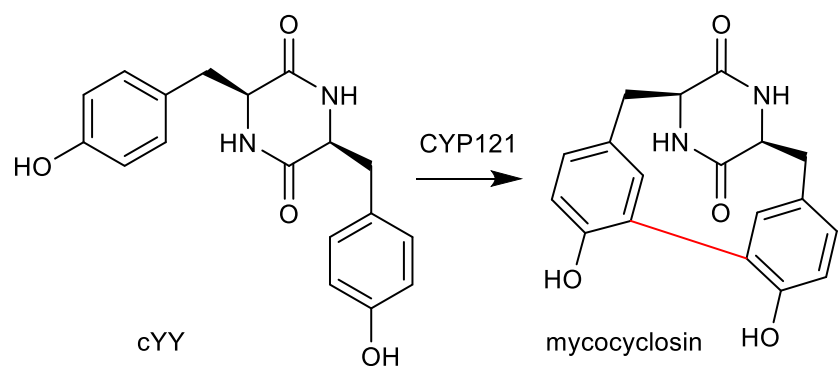

Fig. 5 Conversion of cYY to mycocyclosin by the $\mathrm{P}_{450}$ enzyme CYP121 in Mycobacterium tuberculosis 
<smiles>[R]c1ccc(/C=C2\NC(=O)[C@@H](Cc3c[nH]c4ccccc34)NC2=O)cc1</smiles>

$\mathrm{R}=\mathrm{H} \quad \alpha, \beta$-dehydro $\mathrm{cWF}$ $\mathrm{R}=\mathrm{OH} \alpha, \beta$-dehydro cWY
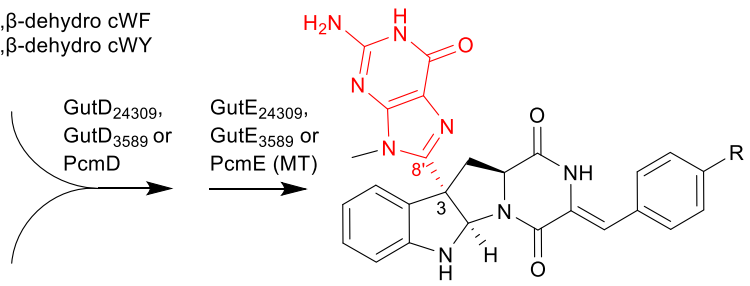<smiles>Nc1nc2[nH]cnc2c(=O)[nH]1</smiles>

$$
\text { guanine }
$$
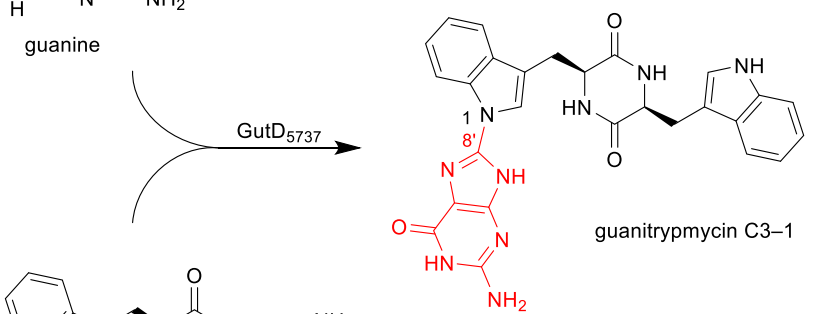<smiles>O=C1N[C@H](Cc2c[nH]c3ccccc23)C(=O)N[C@@H]1Cc1c[nH]c2ccccc12</smiles>

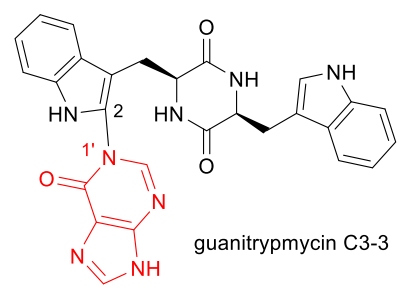<smiles>O=c1[nH]cnc2[nH]cnc12</smiles>

hypoxanthine

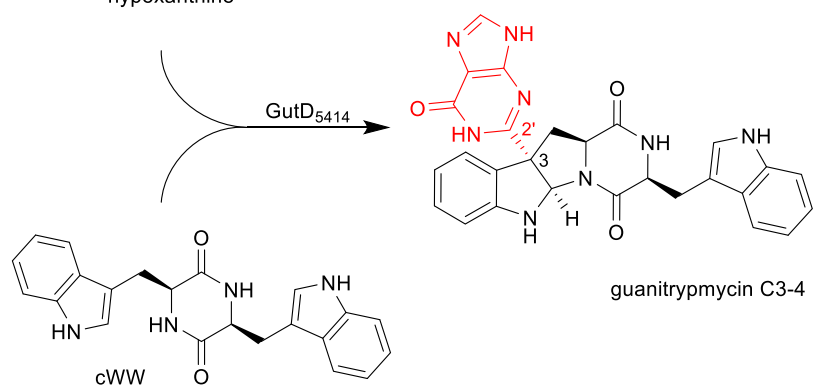

Fig. 6 Coupling reactions of CDPs with nucleobases catalysed by $\mathrm{P}_{450} \mathrm{~S}$

B-3589, catalyse the C3-guaninylation of dehydro CDP derivatives. Subsequent $\mathrm{N}$-methylation at the guanine residue by GutE leads to the formation of $\mathrm{cWY}$ derivative guanitrypmycin A2-1. The BGC from strain B-3589 is also responsible for the formation of the $\mathrm{cWF}$ derivative guanitrypmycin A1-1 (Liu et al. 2019). An almost identical BGC for guanitrypmycin A2-1, termed purincyclamide in that paper, was later identified in Streptomyces chrestomyceticus
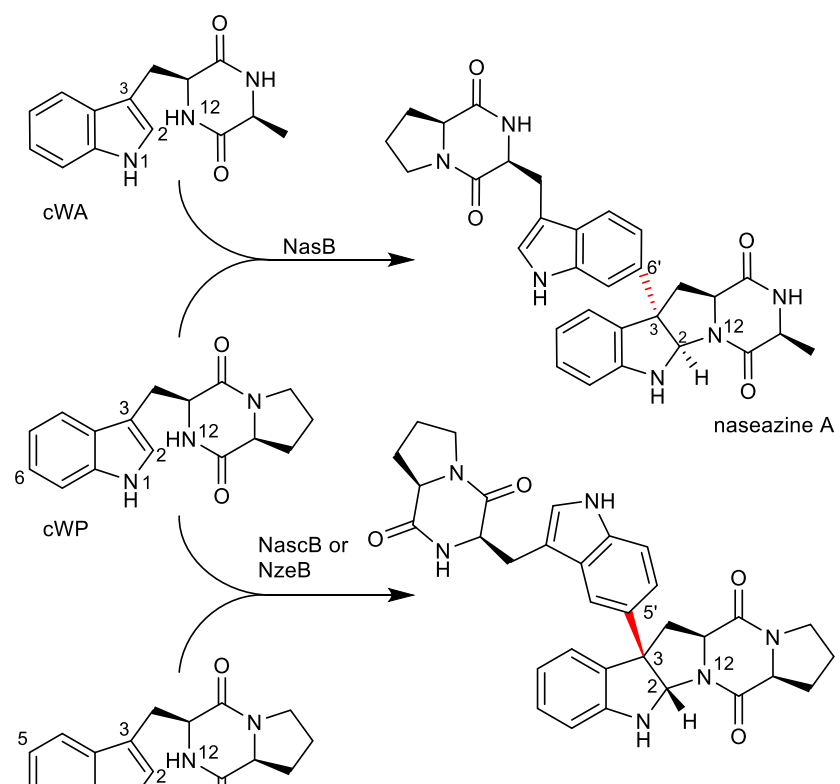

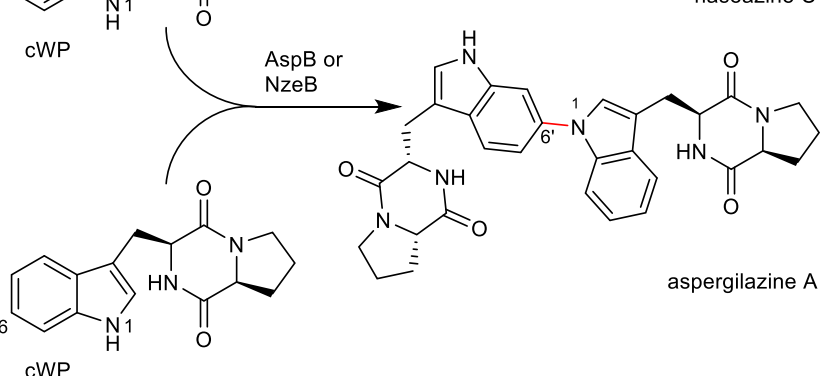

cWP

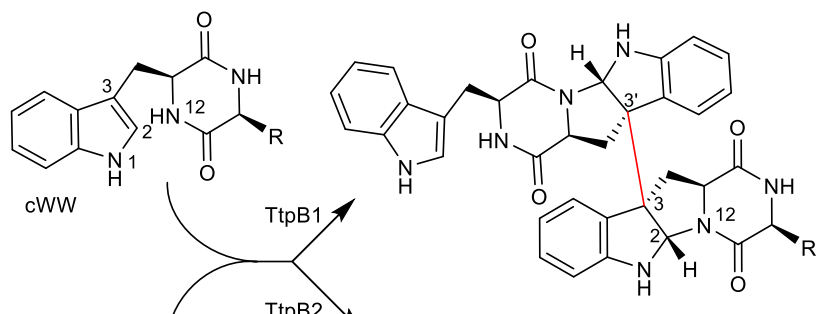

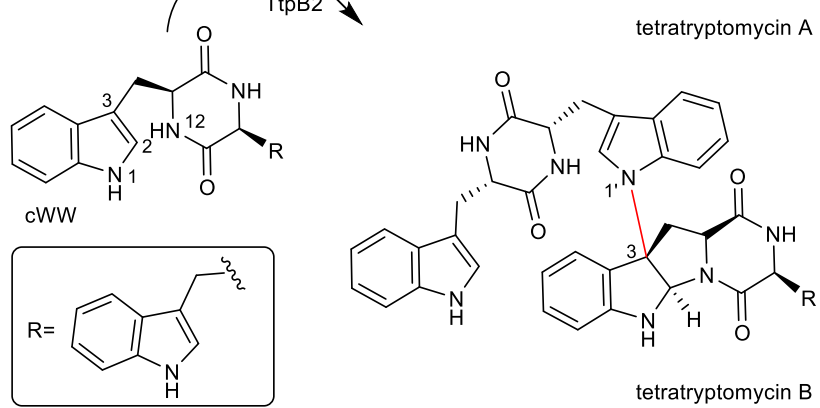

Fig. 7 Dimerisation of CDPs catalysed by $\mathrm{P}_{450} \mathrm{~S}$

NA4264, and the corresponding $\mathrm{P}_{450}$ enzyme was named PcmD (Shi et al. 2019).

Interestingly, the guanine is always attached via $\mathrm{C}^{\prime}$ to either $\mathrm{N} 1$ or $\mathrm{C} 3$ position of the tryptophanyl residue. The first identified $\mathrm{GutD}_{5737}$ catalyses a C-N bond linkage, whereas other three enzymes, GutD ${ }_{24309}, \mathrm{GutD}_{3589}$ and PcmD, a C-C 
Fig. 8 Proposed mechanism for NzeB reaction, modified from Shende et al. (2020)

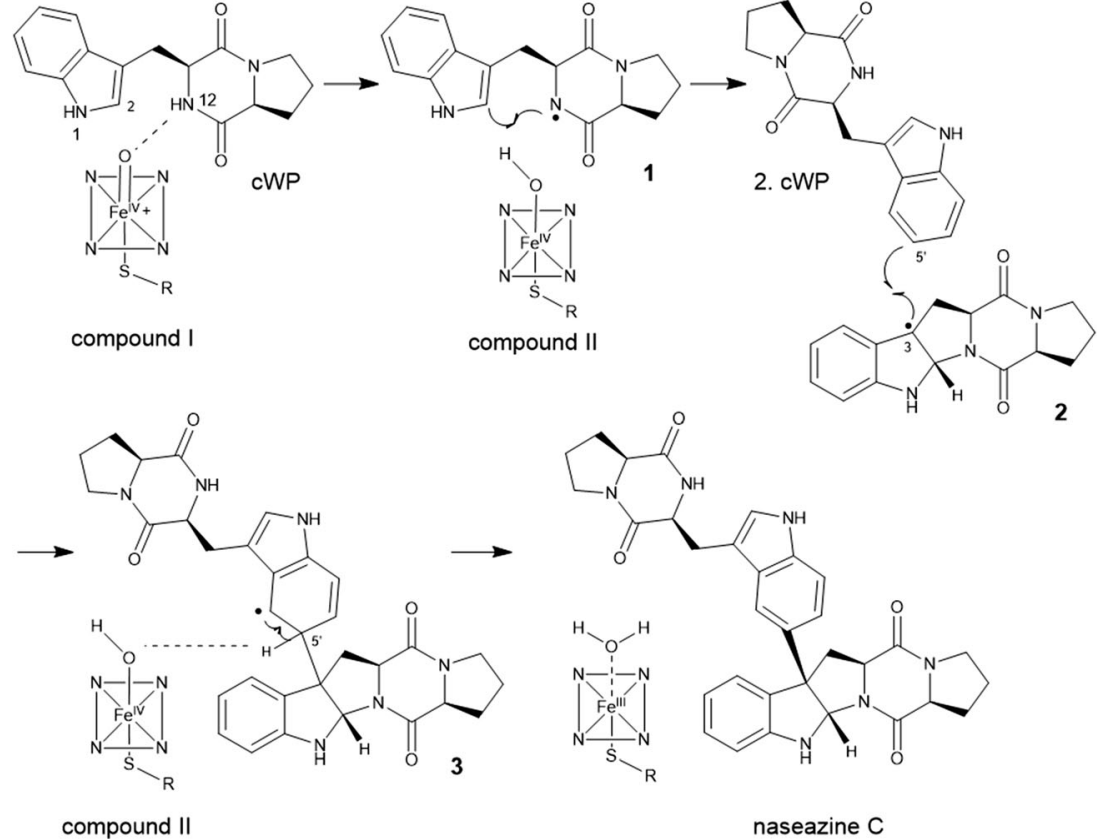

bond formation, followed by a cyclisation between $\mathrm{C} 2$ of the indole and N10 of the DKP rings.

In addition to the guanine transfer reactions, the CDPSassociated $\mathrm{P}_{450}$ s can also catalyse the coupling of CDP with another nucleobase hypoxanthine. GutD 2774 from Streptomyces lavendulae NRRL B-2774 and GutD $_{5414}$ from Streptomyces xanthophaeus NRRL B-5414 use the same substrate cWW and attach hypoxanthine via its $\mathrm{N1}^{\prime}$ to $\mathrm{C} 2$ of the indole and $\mathrm{C}^{\prime}$ to $\mathrm{C} 3$, respectively. The main final pathway products are identified correspondingly as guanitrypmycins C3-3 and C3-4 (see Fig. 6). GutD 2774 and GutD 5414 share sequence identities of 75 and $57 \%$ on the amino acid level with GutD $_{5737}$ and were also found to be capable of using guanine as substrate, resulting in the formation of the minor side products guanitrypmycins C3-1 and C3-2, respectively (Yu et al. 2019). Although guanitrypmycins are unusual bacterial metabolites, no pharmacological and biological properties have been published yet, and their biological function remains therefore unknown. One important reason is their low solubility in aqueous milieu.

\section{$\mathbf{P}_{450}$ S as DKP dimerases for C-C bond formation}

At least four CDPS-associated $\mathrm{P}_{450} \mathrm{~s}$ catalyse dimerisation of tryptophan-containing CDPs via an intermolecular C-C bond formation between the two tryptophanyl moieties (Fig. 7). Their products are connected via $\mathrm{C} 3$ of one tryptophanyl moiety, accompanied by a cyclisation between $\mathrm{C} 2$ and N12 based on a Mannich reaction to form a pyrroloindoline system, in analogy to guanitrypmycins mentioned above (Tian et al. 2018).
Among the characterised CDP dimerases, NasB from Streptomyces sp. NRRL S-1868 uses cWP and cWA as substrates, resulting in the formation of naseazine A with a C3-C6' linkage as the mere product (Yu and Li 2019). NascB from Streptomyces sp. CMB-MQ030 (Tian et al. 2018) and NzeB from Streptomyces sp. NRRL F-5053 (Shende et al. 2020) are cWP dimerases for C3-C5' coupling with naseazine $\mathrm{C}$ as the main product. Two twogene operons from Saccharopolyspora antimicrobica DSM 45119 are responsible for the formation of tetratryptomycins with four tryptophanyl units. TtpB1 catalyses C3-C3'connection between two cWW molecules (Liu et al. 2020). In vitro bioactivity testes revealed that naseazine $\mathrm{C}$ showsactivity against chloroquine-sensitive malaria parasites and its derivatives have protective activity against glutamate-induced PC-12 damage (Tian et al. 2018).

\section{$\mathrm{P}_{450} \mathrm{~S}$ as DKP dimerases for $\mathrm{C}-\mathrm{N}$ bond formation}

The aforementioned NzeB also catalyses the N1-C6' dimerisation of two cWP molecules, resulting in the formation of aspergilazine A as minor side product (Shende et al. 2020). Aspergilazine A was identified as the main product of a twogene BGC from Streptomyces sp. NRRL S-1868, with AspB as the responsible dimerase ( $\mathrm{Yu}$ and $\mathrm{Li} 2019$ ).

The second two-gene operon from Saccharopolyspora antimicrobica DSM 45119 is responsible for the formation of tetratryptomycin B. The P450 TtpB2 catalyses dimerisation of cWW via C3-N1' coupling (see Fig. 7) (Liu et al. 2020). 
Tetratryptomycin B shows no antibacterial effects on cell lines of E. coli, Bacillus subtilis, Staphylococcus aureus or Pseudomonas aeruginosa.

\section{Structural basis and reaction mechanisms}

The first crystal structure of the CDPS-associated $\mathrm{P}_{450} \mathrm{~S}$ CYP121 from Mycobacterium tuberculosis has been solved in 2009 (Belin et al. 2009). Based on the structure together with QM/MM studies, a reaction mechanism with involvement of two radicals was proposed (Dumas et al. 2014). One tyrosyl residue is bound closely to the haem centre in proximity to the key oxidant species of $\mathrm{P}_{450} \mathrm{~s}$, whereas the other tyrosyl moiety points to the protein surface. The important intermediates bear unpaired electrons at ortho-position to the hydroxyl groups of both phenyl moieties. Intramolecular connection of the two radicals leads to the formation of mycocyclosin (Fig. 5) (Dumas et al. 2014).

Very recently, two groups published the structure of the same $\mathrm{P}_{450}$ from Streptomyces sp. NRRL F-5053, termed NzeB and $\mathrm{Nas}_{\mathrm{F} 5053}$, respectively (Shende et al. 2020; Sun et al. 2020). It was proposed that the dimerisation of cWP catalysed by this enzyme would also be via a radicalmediated mechanism (Fig. 8) (Shende et al. 2020). In contrast to CYP121, this dimerase only forms one radical at nitrogen N1 (Sun et al. 2020) or N12 (Shende et al. 2020) after abstraction of one hydrogen by compound I (intermediate 1). In the mechanism proposed by Shende et al. (2020), the resulting radical then shifts to $\mathrm{C} 3$ after cyclisation between N12 and $\mathrm{C} 2$ (intermediate 2). The $\mathrm{C} 3$ radical attacks subsequently C5' of the tryptophanyl moiety of the second CDP (intermediate 3), followed by a re-aromatisation via elimination of the C5'-hydrogen mediated by compound II, resulting in naseazine $\mathrm{C}$. Regarding the intermolecular $\mathrm{C}-\mathrm{N}$ bond formation, a similar radical-mediated mechanism is strongly favoured (Shende et al. 2020). In contrast to the C-C dimerisation, the first hydrogen is abstracted from $\mathrm{N} 1$ instead of N12. The subsequent steps take place in analogy to those of $\mathrm{C}-\mathrm{C}$ bond formation.

Sequence alignments of NascB, NzeB (synonym $\mathrm{Nas}_{\mathrm{F} 5053}$ ) and $\mathrm{Nas}_{\mathrm{S} 1868}$ (synonym AspB) revealed four critical amino acid residues in these $\mathrm{P}_{450}$ s controlling the regio- and stereoselectivity. Mutation on the key residues at positions $65,86,284$ and 288 led to the alteration of the regio- and stereospecificity of these enzymes (Sun et al. 2020).

\section{Conclusion}

In this review, we summarised the intriguing reactions catalysed by bacterial CDPS-associated $\mathrm{P}_{450}$ s like DKP ring aromatisation, CDP dimerisation and nucleobase transfer reactions. These $\mathrm{P}_{450}$ s have the advantages that they are soluble proteins and can be easily overproduced in E. coli. Some of them show a flexible substrate tolerance towards CDP analogues (Tian et al. 2018), which could be used for production of designed CDP derivatives by chemoenzymatic and synthetic biological approaches, e.g. by recombination of different genes for CDPS, $\mathrm{P}_{450} \mathrm{~s}$ or for other enzymes like prenyltransferases (Dubois et al. 2019).

Genome sequencing revealed the presence of a large number of $c d p s$-containing BGCs including those with $\mathrm{P}_{450} \mathrm{~S}$ as tailoring enzymes. More than 700 of such BGCs were identified in 93107 prokaryotic genomes (Skinnider et al. 2018). The number of the clusters of interest will undoubtedly increase with the number of ongoing sequencing projects. Targeted gene activation might not only uncover novel natural products but also reveal new functions of tailoring enzymes including $\mathrm{P}_{450} \mathrm{~s}$.

Authors' contribution The manuscript was written through contribution of all authors. All authors conducted literature research. LH prepared the tables and figures. All authors have given approval to the final version of the manuscript.

Funding Open Access funding enabled and organized by Projekt DEAL. The works in the author's laboratory were funded in part by the Deutsche Forschungsgemeinschaft (DFG, Li844/14-1 and INST 160/620-1)

\section{Declarations}

Ethics approval This article does not contain any studies with human participants or animals performed by any of the authors.

Conflict of interest The authors declare no competing interests.

Open Access This article is licensed under a Creative Commons Attribution 4.0 International License, which permits use, sharing, adaptation, distribution and reproduction in any medium or format, as long as you give appropriate credit to the original author(s) and the source, provide a link to the Creative Commons licence, and indicate if changes were made. The images or other third party material in this article are included in the article's Creative Commons licence, unless indicated otherwise in a credit line to the material. If material is not included in the article's Creative Commons licence and your intended use is not permitted by statutory regulation or exceeds the permitted use, you will need to obtain permission directly from the copyright holder. To view a copy of this licence, visit http://creativecommons.org/licenses/by/4.0/.

\section{References}

Alkhalaf LM, Ryan KS (2015) Biosynthetic manipulation of tryptophan in bacteria: pathways and mechanisms. Chem Biol 22:317-328

Belin P, Le Du MH, Fielding A, Lequin O, Jacquet M, Charbonnier JB, Lecoq A, Thai R, Courcon M, Masson C, Dugave C, Genet R, Pernodet JL, Gondry M (2009) Identification and structural basis of the reaction catalyzed by CYP121, an essential cytochrome 
P450 in Mycobacterium tuberculosis. Proc Natl Acad Sci U S A 106:7426-7431

Borgman P, Lopez RD, Lane AL (2019) The expanding spectrum of diketopiperazine natural product biosynthetic pathways containing cyclodipeptide synthases. Org Biomol Chem 17:2305-2314

Borthwick AD (2012) 2,5-Diketopiperazines: synthesis, reactions, medicinal chemistry, and bioactive natural products. Chem Rev 112: 3641-3716

Cain CC, Lee D, Waldo RH III, Henry AT, Casida EJ Jr, Wani MC, Wall ME, Oberlies NH, Falkinham JO III (2003) Synergistic antimicrobial activity of metabolites produced by a nonobligate bacterial predator. Antimicrob Agents Chemother 47:2113-2117

Canu N, Moutiez M, Belin P, Gondry M (2020) Cyclodipeptide synthases: a promising biotechnological tool for the synthesis of diverse 2,5-diketopiperazines. Nat Prod Rep 37:312-321

Chen C-C, Min J, Zhang L, Yang Y, Yu X, Guo R-T (2021) Advanced understanding of electron transfer pathway of cytochrome P450s. Chembiochem https://doi.org/10.1002/cbic.202000705

Cryle MJ, Bell SG, Schlichting I (2010) Structural and biochemical characterization of the cytochrome P450 CypX (CYP134A1) from Bacillus subtilis: a cyclo-L-leucyl-L-leucyl dipeptide oxidase. Biochemistry 49:7282-7296

Dubois P, Correia I, Le CF, Dubois S, Jacques I, Canu N, Moutiez M, Thai R, Gondry M, Lequin O, Belin P (2019) Reprogramming Escherichia coli for the production of prenylated indole diketopiperazine alkaloids. Sci Rep 9:9208

Dumas VG, Defelipe LA, Petruk AA, Turjanski AG, Marti MA (2014) $\mathrm{QM} / \mathrm{MM}$ study of the $\mathrm{C}-\mathrm{C}$ coupling reaction mechanism of CYP121, an essential cytochrome p450 of Mycobacterium tuberculosis. Proteins 82:1004-1021

Giessen TW, Marahiel MA (2015) Rational and combinatorial tailoring of bioactive cyclic dipeptides. Front Microbiol 6:785

Giessen TW, von Tesmar AM, Marahiel MA (2013a) A tRNA-dependent two-enzyme pathway for the generation of singly and doubly methylated ditryptophan 2,5-diketopiperazines. Biochemistry 52:4274 4283

Giessen TW, von Tesmar AM, Marahiel MA (2013b) Insights into the generation of structural diversity in a tRNA-dependent pathway for highly modified bioactive cyclic dipeptides. Chem Biol 20:828-838

Gondry M, Sauguet L, Belin P, Thai R, Amouroux R, Tellier C, Tuphile K, Jacquet M, Braud S, Courcon M, Masson C, Dubois S, Lautru S, Lecoq A, Hashimoto S, Genet R, Pernodet JL (2009) Cyclodipeptide synthases are a family of tRNA-dependent peptide bond-forming enzymes. Nat Chem Biol 5:414-420

Gondry M, Jacques IB, Thai R, Babin M, Canu N, Seguin J, Belin P, Pernodet JL, Moutiez M (2018) A comprehensive overview of the cyclodipeptide synthase family enriched with the characterization of 32 new enzymes. Front Microbiol 9:46

Harding E (2020) WHO global progress report on tuberculosis elimination. Lancet Respir Med 8:19

Izoré T, Cryle MJ (2018) The many faces and important roles of proteinprotein interactions during non-ribosomal peptide synthesis. Nat Prod Rep 35:1120-1139

Katagiri M, Ganguli BN, Gunsalus IC (1968) A soluble cytochrome P450 functional in methylene hydroxylation. J Biol Chem 243:35433546

Klingenberg M (1957) Pigments of rat liver microsomes. Arch Biochem Biophys 409:2-6

Kohn H, Widger W (2005) The molecular basis for the mode of action of bicyclomycin. Curr Drug Targets Infect Disord 5:273-295

Lautru S, Gondry M, Genet R, Pernodet JL (2002) The albonoursin gene cluster of $S$. noursei: biosynthesis of diketopiperazine metabolites independent of nonribosomal peptide synthetases. Chem Biol 9: $1355-1364$
Lawson MR, Dyer K, Berger JM (2016) Ligand-induced and smallmolecule control of substrate loading in a hexameric helicase. Proc Natl Acad Sci U S A 113:13714-13719

Le Chevalier F, Correia I, Matheron L, Babin M, Moutiez M, Canu N, Gondry M, Lequin O, Belin P (2020) In vivo characterization of the activities of novel cyclodipeptide oxidases: new tools for increasing chemical diversity of bioproduced 2,5-diketopiperazines in Escherichia coli. Microb Cell Factories 19:178

Liu J, Xie X, Li S-M (2019) Guanitrypmycin biosynthetic pathways imply cytochrome P450-mediated regio- and stereospecific guaninyl transfer reactions. Angew Chem Int Ed Eng 58:11534 11540

Liu J, Xie X, Li S-M (2020) Increasing cytochrome P450 enzyme diversity by identification of two distinct cyclodipeptide dimerases. Chem Commun (Camb) 56:11042-11045

McLean KJ, Carroll P, Lewis DG, Dunford AJ, Seward HE, Neeli R, Cheesman MR, Marsollier L, Douglas P, Smith WE, Rosenkrands I, Cole ST, Leys D, Parish T, Munro AW (2008) Characterization of active site structure in CYP121. A cytochrome P450 essential for viability of Mycobacterium tuberculosis H37Rv. J Biol Chem 283: 33406-33416

Meng S, Han W, Zhao J, Jian XH, Pan HX, Tang GL (2018) A sixoxidase cascade for tandem $\mathrm{C}-\mathrm{H}$ bond activation revealed by reconstitution of bicyclomycin biosynthesis. Angew Chem Int Ed Eng 57: 719-723

Mikulski L, Schäfer J, Brockmeyer K, Kraut R, Li S-M (2020) Comparative studies on similarities and differences of cyclodipeptide oxidases for installation of $\mathrm{C}-\mathrm{C}$ double bonds at the diketopiperazine ring. Appl Microbiol Biotechnol 104:2523-2536

Minelli A, Grottelli S, Mierla A, Pinnen F, Cacciatore I, Bellezza I (2012) Cyclo(His-Pro) exerts anti-inflammatory effects by modulating NF$\mathrm{kB}$ and Nrf2 signalling. Int $\mathrm{J}$ Biochem Cell Biol 44:525-535

Moutiez M, Belin P, Gondry M (2017) Aminoacyl-tRNA-utilizing enzymes in natural product biosynthesis. Chem Rev 117:5578-5618

Musetti R, Polizzotto R, Vecchione A, Borselli S, Zulini L, D’Ambrosio M, di Toppi LS, Pertot I (2007) Antifungal activity of diketopiperazines extracted from Alternaria alternata against Plasmopara viticola: an ultrastructural study. Micron 38:643-650

Newman DJ, Cragg GM (2020) Natural products as sources of new drugs over the nearly four decades from $01 / 1981$ to $09 / 2019$. J Nat Prod 83:770-803

Patteson JB, Cai W, Johnson RA, Santa Maria KC, Li B (2017) Identification of the biosynthetic pathway for the antibiotic bicyclomycin. Biochemistry 57:61-65

Payne JA, Schoppet M, Hansen MH, Cryle MJ (2017) Diversity of nature's assembly lines - recent discoveries in non-ribosomal peptide synthesis. Mol BioSyst 13:9-22

Rudolf JD, Chang CY, Ma M, Shen B (2017) Cytochromes P450 for natural product biosynthesis in Streptomyces: sequence, structure, and function. Nat Prod Rep 34:1141-1172

Shende VV, Khatri Y, Newmister SA, Sanders JN, Lindovska P, Yu F, Doyon TJ, Kim J, Houk KN, Movassaghi M, Sherman DH (2020) Structure and function of NzeB, a versatile C-C and C-N bondforming diketopiperazine dimerase. J Am Chem Soc 142:1741317424

Shi J, Xu X, Zhao EJ, Zhang B, Li W, Zhao Y, Jiao RH, Tan RX, Ge HM (2019) Genome mining and enzymatic total biosynthesis of purincyclamide. Org Lett 21:6825-6829

Skinnider MA, Johnston CW, Merwin NJ, Dejong CA, Magarvey NA (2018) Global analysis of prokaryotic tRNA-derived cyclodipeptide biosynthesis. BMC Genomics 19:45

Ström K, Sjögren J, Broberg A, Schnürer J (2002) Lactobacillus plantarum MiLAB 393 produces the antifungal cyclic dipeptides cyclo(L-Phe-L-Pro) and cyclo(L-Phe-trans-4-OH-L-Pro) and 3phenyllactic acid. Appl Environ Microbiol 68:4322-4327 
Sun C, Luo Z, Zhang W, Tian W, Peng H, Lin Z, Deng Z, Kobe B, Jia X, $\mathrm{Qu} X$ (2020) Molecular basis of regio- and stereo-specificity in biosynthesis of bacterial heterodimeric diketopiperazines. Nat Commun 11:6251

Tian W, Sun C, Zheng M, Harmer JR, Yu M, Zhang Y, Peng H, Zhu D, Deng Z, Chen SL, Mobli M, Jia X, Qu X (2018) Efficient biosynthesis of heterodimeric $\mathrm{C}^{3}$-aryl pyrroloindoline alkaloids. Nat Commun 9:4428

Uffen RL, Canale-Parola E (1972) Synthesis of pulcherriminic acid by Bacillus subtilis. J Bacteriol 111:86-93

Vior NM, Lacret R, Chandra G, Dorai-Raj S, Trick M, Truman AW (2018) Discovery and biosynthesis of the antibiotic bicyclomycin in distantly related bacterial classes. Appl Environ Microbiol 84: e02828-e02817

Waring P, Beaver J (1996) Gliotoxin and related epipolythiodioxopiperazines. Gen Pharmacol 27:1311-1316

Witwinowski J, Moutiez M, Coupet M, Correia I, Belin P, Ruzzini A, Saulnier C, Caraty L, Favry E, Seguin J, Lautru S, Lequin O, Gondry M, Pernodet JL, Darbon E (2019) Study of bicyclomycin biosynthesis in Streptomyces cinnamoneus by genetic and biochemical approaches. Sci Rep 9:20226

Xu W, Gavia DJ, Tang Y (2014) Biosynthesis of fungal indole alkaloids. Nat Prod Rep 31:1474-1487

Yamazaki Y, Tanaka K, Nicholson B, Deyanat-Yazdi G, Potts B, Yoshida T, Oda A, Kitagawa T, Orikasa S, Kiso Y, Yasui H, Akamatsu M, Chinen T, Usui T, Shinozaki Y, Yakushiji F, Miller BR, Neuteboom S, Palladino M, Kanoh K, Lloyd GK, Hayashi Y (2012) Synthesis and structure-activity relationship study of antimicrotubule agents phenylahistin derivatives with a didehydropiperazine-2,5-dione structure. J Med Chem 55:10561071

Yao T, Liu J, Liu Z, Li T, Li H, Che Q, Zhu T, Li D, Gu Q, Li W (2018) Genome mining of cyclodipeptide synthases unravels unusual tRNA-dependent diketopiperazine-terpene biosynthetic machinery. Nat Commun 9:4091

Yao T, Liu J, Jin E, Liu Z, Li H, Che Q, Zhu T, Li D, Li W (2020) Expanding the structural diversity of drimentines by exploring the promiscuity of two N-methyltransferases. iScience 23:101323

Yu H, Li S-M (2019) Two cytochrome P450 enzymes from Streptomyces sp. NRRL S-1868 catalyze distinct dimerization of tryptophancontaining cyclodipeptides. Org Lett 21:7094-7098

Yu H, Xie X, Li S-M (2018) Coupling of guanine with cyclo-L-Trp-LTrp mediated by a cytochrome P450 homologue from Streptomyces purpureus. Org Lett 20:4921-4925

Yu H, Xie X, Li S-M (2019) Coupling of cyclo-L-Trp-L-Trp with hypoxanthine increases the structure diversity of guanitrypmycins. Org Lett 21:9104-9108

Zhang Q, Li S, Chen Y, Tian X, Zhang H, Zhang G, Zhu Y, Zhang S, Zhang W, Zhang C (2013) New diketopiperazine derivatives from a deep-sea-derived Nocardiopsis alba SCSIO 03039. J Antibiot 66: $31-36$

Publisher's note Springer Nature remains neutral with regard to jurisdictional claims in published maps and institutional affiliations. 